\title{
ФАКТОРЫ РИСКА РАЗВИТИЯ НЕСОСТОЯТЕЛЬНОСТИ МЫШЦ ТАЗОВОГО ДНА У ЖЕНЩИН
}

\section{DEVELOPMENT RISK FACTORS INSURANCE OF THE PELVIC FLOOR MUSCLES IN WOMEN}

\section{F. Salpagarova}

Summary. The article discusses the main risk factors for pelvic floor muscle failure. In recent years, studies have shown that pelvic floor muscle failure is a multifactorial disease. In the literature, there are conflicting data on the influence of various risk factors on the development of pelvic floor muscle failure, which requires further study. Clarification of their role in the formation of insolvency of the pelvic floor muscles will make it possible to develop optimal preventive and therapeutic measures in relation to this pathology in accordance with the modern patient-oriented approach.

Keywords: failure of the pelvic floor muscles, pelvic organ prolapse, risk factors, birth injury, connective tissue dysplasia.
Салпагарова Фарида Хаджи-Магаметовна

Аспирант, Ставропольский Государственный Медицинский Университет fsalpagarova@list.ru

Аннотация. В статье обсуждаются основные факторы риска развития несостоятельности мышц тазового дна. Согласно результатам проведенных в последние годы исследований, несостоятельность мышц тазового дна является мультифакториальным заболеванием. В литературных источниках приводятся противоречивые данные о влиянии различных факторов риска на развитие несостоятельности мышц тазового дна, что требует дальнейшего изучения. Уточнение их роли в формировании несостоятельности мышц тазового дна позволит разработать оптимальные профилактические и лечебные мероприятия в отношении данной патологии в соответствии с современным пациент-ориентированным подходом.

Ключевые слова: несостоятельность мышц тазового дна, пролапс тазовых органов, факторы риска, родовая травма, дисплазия соединительной ткани.

годы отмечается тенденция к увеличению доли женщин репродуктивного возраста с НМТД.

В США проведено крупномасштабное исследование, согласно которому частота развития опущения тазовых органов прямо пропорционально зависит от возраста, паритета и массы тела. При этом различий в распространенности этого заболевания у женщин разных этнических групп обнаружено не было [27]. Однако в исследовании Sewell C.A. et al. (2007) выявлены различия по частоте генитального пролапса у женщин разных расовых групп [30]. В работе Jakus-Waldman S. et al. (2020) показано, что принадлежность к латиноамериканской этнической группе является одним из ФР неудовлетворительных результатов хирургического лечения пролапса тазовых органов в отдаленном периоде [28].

Важную роль в развитии НМТД играет наследственная предрасположенность [25]. Зафиксированы случаи врожденного пролапса тазовых органов [24]. Имеются данные о высокой частоте НМТД в отдельных семьях и у однояйцовых близнецов, однако вклад конкретных генов в патогенез НМТД остается малоизученным [32].

Многие авторы сходятся во мнении, что акушерская травма промежности является пусковым механизмом 
в развитии НМТД, приводящим при прогрессировании к пролапсу тазовых органов [1, 7, 23]. Причем, это могут быть как одни нормальные вагинальные роды, так и повторные роды, роды крупным плодом, роды, сопровождающиеся разрывом промежности или перинеотомией, быстрые и стремительные роды [4, 33]. Имеются сведения о взаимосвязи количества родов и частоты НМТД [20]. По некоторым данным, любая беременность сроком более 20 недель, независимо от способа родоразрешения, повышает риск НМТД [3]. Высказывается мнение, что любые вмешательства в малом тазу, сопровождающиеся дезинтеграцией структурных единиц мышечно-связочного аппарата половых органов, способствуют формированию генитального пролапса [3].

В то же время, по мнению Смольновой Т.Ю. (2015), вклад родового травматизма в генез пролапса тазовых органов не превышает 20\% [14]. Подтверждением может служить тот факт, что у трети женщин с генитальным пролапсом и вагинальными родами в анамнезе не зафиксированы травмы промежности [22]. Кроме того, НМТД встречается у нерожавших женщин и этиология заболевания в этой категории пациенток остается не до конца ясной. По данным Зиганшина А.М и соавт. (2018), ФР пролапса тазовых органов у нерожавших женщин являются тяжелые проявления дисплазии соединительной ткани (ДСТ), избыточная масса тела, тяжелый физический труд, возраст старше 60 лет, а также наличие экстрагенитальной патологии [19].

В последние годы ДСТ активно изучается в качестве причины НМТД. Высказывается мнение, что патологические изменения соединительной ткани способствуют развитию НМТД даже в большей степени, чем роды и акушерские травмы, и без ДСТ не возникает клинически значимых нарушений функционирования тазового дна после родов [13]. Развитие пролапса тазовых органов у женщин репродуктивного возраста после единственных физиологических родов при отсутствии других значимых ФР часто рассматривают как проявление генерализованной ДСТ. В работе Оразова М.3. и соавт. (2018) выявлено, что дезорганизация соединительной ткани при НМТД обусловлена изменением внутриклеточного метаболизма фибробластов на молекулярном уровне вследствие оксидативного стресса [12]. По данным литературы, наиболее частым проявлением ДСТ у женщин с НМТД является гипермобильность суставов - 82,6\% случаев [15]. Сроки формирования пролапса тазовых органов зависят от степени выраженности ДСТ. Форма генитального пролапса определяется типом гемодинамики и микроциркуляции, которые, в свою очередь, определяются формой ДСТ [14]. Вместе с тем, вклад ДСТ в развитие НМТД требует дальнейшего изучения, поскольку данный синдром подтверждается не более чем у $1 \%$ людей в популяции, тогда как рас- пространенность НМТД среди женщин значительно выше [18].

Традиционным ФР НМТД считается длительное и чрезмерное повышение внутрибрюшного давления, связанное с запорами, длительным упорным кашлем, тяжелым физическим трудом, занятиями спортом, длительной статической позой, наличием новообразований брюшной полости $[8,21]$.

Обсуждается роль нарушения биоценоза влагалища в развитии НМТД [16].

Изучается влияние недостатка магния в патогенезе дезорганизации соединительной ткани и формировании НМТД [17].

Определенный вклад в развитие НМТД вносит гипоэстрогения. Дефицит эстрогенов сопровождается снижением репаративных возможностей тканей, уменьшением эластичности и количества коллагеновых волокон в соединительной ткани, клеточной атрофией, дегенерацией нервных окончаний, снижением тонуса гладкой мускулатуры, истончением влагалищного и уретрального эпителия, ухудшением кровоснабжения мышц малого таза [11]. Все это в комплексе может способствовать развитию НМТД. Однако у всех женщин после 50 лет в большей или меньшей степени присутствует гипоэстрогения, но не во всех случаях диагностируется НМТД.

Физиологическая кривизна позвоночника защищает тазовые органы от прямой передачи внутрибрюшного давления на тазовое дно. По данным Худяева А.Т. и соавт. (2007), пусковым фактором развития НМТД может быть поясничный остеохондроз и врожденные аномалии позвоночника, которые сопровождаются нарушением кривизны позвоночника [2].

На сегодняшний день имеются данные о негативном вкладе повышенной массы тела в развитие НМТД и пролапса тазовых органов, а также рецидивов заболевания [26].

Инфекции мочевыводящих путей нередко сопровождаются транзиторным недержанием мочи, что в сочетании с атрофическими изменениями, характерными для менопаузы, многократно повышают риск развития НМТД [6].

Зиганшин А.М. и Кулавский В.А. (2016) выявили существенное влияние на организм женщин с опущением или пролапсом тазовых органов модифицированных ФР (масса тела, уровень физической активности, разрывы промежности, масса детей при рождении) 
в 93\% случаях, тогда как вклад немодифицированных ФР (возраст, наследственность, наличие соматических заболеваний) составляет не более $30 \%$ [5].

Таким образом, результаты многочисленных исследований свидетельствуют, что НМТД является мульти- факториальным заболеванием. Однако роль конкретных ФР требует дальнейшего анализа. Изучение вклада различных ФР в развитие НМТД позволит разработать оптимальные профилактические и лечебные мероприятия в отношении данной патологии в соответствии с современным пациент-ориентированным подходом.

\section{ЛИТЕРАТУРА}

1. Вазенмиллер Д.В., Абатов Н.Т., Бащжанова Ж.О. Вагинальные роды как фактор развития пролапса гениталий // Медицина и экология. 2015. № 4. C. 77-79.

2. Влияние аномалий развития поясничного отдела позвоночника и поясничного остеохондроза на состояние тазового дна и пролапс гениталий у женщин / А.Т. Худяев [и др.] // Гений Ортопедии. 2007. № 3. С. 89-94.

3. Гутикова Л.В. Пролапс гениталий: современное состояние проблемы // Журнал Гродненского государственного медицинского университета. 2012. № 1. C. 86-89.

4. Доброхотова Ю.Э., Нагиева Т.С. Дисфункция тазового дна у женщин репродуктивного периода, синдром релаксированного влагалища — необходимость реабилитации в послеродовом периоде // РМЖ. Мать и дитя. 2017. № 15. С. 1121-1124.

5. Зиганшин А.М., Кулавский В.А. Метод прогнозирования факторов риска развития пролапса тазовых органов // Таврический медико-биологический вестник. 2016. Т. 19. № 2. С. 65-68.

6. Имельбаева А.Г. Нарушения мочевыделительной системы при пролапсе гениталий и их коррекция. Автореф. дисс. канд. мед.наук. Уфа, 2019.25 с.

7. Кажина М.В. Акушерские проблемы тазового дна // Охрана материнства и детства. 2017. № 1(29). С. 47-51.

8. Камоева С.В. Ранняя диагностика развивающегося пролапса тазовых органов у женщин репродуктивного возраста при отсутствии клинических признаков // Лечение и профилактика. 2013. Т. 2. № 6. С. 88-91.

9. Короткевич 0.С., Мозес В.Г. Эффективность предложенного способа объективной оценки степени пролапса тазового дня у женщин // Мать и дитя в Кузбассе. 2017. № 3 (70). С. 40.

10. Кулавский В.А., Зиганшин А.М., Кулавский Е.В. Несостоятельность мышц тазового дна // Мать и дитя в Кузбассе. 2012. № 3(50). С. 8-14.

11. Медицина климактерия /под ред. В.П. Сметник. Ярославль, 2006. 848 с.

12. Молекулярная морфология стенки влагалища при несостоятельности тазового дна / М.3. Оразов [и др.]. // Молекулярная медицина. 2018. Т. 16. № 6. C. 56-59.

13. Роль дисплазии соединительной ткани в акушерско-гинекологической практике / А.С. Гаспаров [и др.] // Казанский медицинский журнал. 2014. Т. 95. № 6. C. 897-904.

14. Смольнова Т.Ю. Пролапс гениталий и дисплазия соединительной ткани // Клиническая и экспериментальная хирургия. Журнал им. акад. Б.В. Петровского. 2015. № 2. С. 53-64.

15. Смольнова Т.Ю., Адамян Л.В. Динамика фенотипических признаков синдрома дисплазии соединительной ткани в различные возрастные периоды. Актуальность проблемы в акушерстве и гинекологии // Акушерство и гинекология. 2013. № 4. С. 74-79.

16. Современные представления о проблеме несостоятельности мышц тазового дна / М.3. Оразов [и др.]. // Трудный пациент. 2018. Т. 16. № 8-9. С. 25-29.

17. Торшин И.Ю., Громова 0.А. Дисплазия соединительной ткани, клеточная биология и молекулярные механизмы в0здействия магния // РМЖ. 2008. № 4. C. 230.

18. Фенотипический симптомокомплекс дисплазии соединительной ткани у женщин / Т.Ю. Смольнова [и др.] // Клиническая медицина. 2003. № 8. С. 4248.

19. Характеристика факторов риска и клинических проявлений пролапса гениталий у нерожавших женщин / А.М. Зиганшин [и др.] // Акушерство и гинекология: новости, мнения, обучение. 2018. № 2. С. 58-63.

20. How do delivery mode and parity affect pelvic organ prolapse? / A.Ö. Yeniel [et al.] // Acta Obstet Gynecol Scand. 2013. Vol.92. No 7. P. 847-851.

21. Iglesia C.B., Smithling K.R. Pelvic Organ Prolapse // Am Fam Physician. 2017. Vol. 96. № 3. P. 179-185.

22. Kerkhof M.H., Hendriks L., Brolmann H.A. Changes in connective tissue in patients with pelvic organ prolapse - a review of the current literature // Int. Urogynecol. J. Pelvic Floor Dysfunct. 2009. Vol. 20. No 4. P. 461-474.

23. Mirskaya M., Lindgren E.C., Carlsson I.M. Online reported women's experiences of symptomatic pelvic organ prolapse after vaginal birth // BMC Womens Health. 2019. Vol.19. No 1. P. 129.

24. Neonatal genital prolapse / A.M. Taksande, K.Y. Vilhekar, P. Batra, M.J. Jain // Indian Med. Assoc. 2011. Vol. 109. № 7. P. 502-503.

25. Niu K., Chen X., Lu Y. COL3A1 rs 1800255 polymorphism is associated with pelvic organ prolapse susceptibility in Caucasian individuals: Evidence from a metaanalysis // PLoS One. 2021. Vol.16. No 4. e0250943.

26. Obesity and pelvic organ prolapse / U.J. Lee, M.H. Kerkhof, S.A. van Leijsen, J.P. Heesakkers // Curr Opin Urol. 2017. Vol.27. No 5. P. 428-434.

27. Prevalence of symptomatic pelvic floor disorders in US women / I. Nygaard [et al.] // JAMA. 2008. Vol. 300. № 11. P. 1311-1316. 
28. Risk Factors for Surgical Failure and Worsening Pelvic Floor Symptoms Within 5 Years After Vaginal Prolapse Repair / S. Jakus-Waldman [et al.] // Obstet Gynecol. 2020. Vol. 136. № 5. P. 933-941.

29. Sarbacher C.A., Halper J.T. Connective Tissue and Age-Related Diseases // Subcell Biochem. 2019. Vol. 91. P. 281-310.

30. Sewell C.A., Chang E., Sultana C.J. Prevalence of genital prolapse in 3 ethnic groups // J Reprod Med. 2007. Vol.52. No 9. P. 769-773.

31. Siddiqui N.Y., Edenfield A.L. Clinical challenges of the vaginal prolapse // Int J Womens Health. 2014. Vol. 16. № 6. P. 83-94.

32. Systematic review and meta-analysis of genetic association studies of pelvic organ prolapse / K. Allen-Brady [et al.] // Int Urogynecol J. 2021.

33. The effect of episiotomy on pelvic organ prolapse assessed by pelvic organ prolapse quantification system / H. Aytan, E.C. Tok, D. Ertunc, 0. Yasa // Eur J Obstet Gynecol Reprod Biol. 2014. Vol. 173. P. 34-37.

(с Салпагарова Фарида Хаджи-Магаметовна ( fsalpagarova@list.ru ).
Журнал «Современная наука: актуальные проблемы теории и практики»

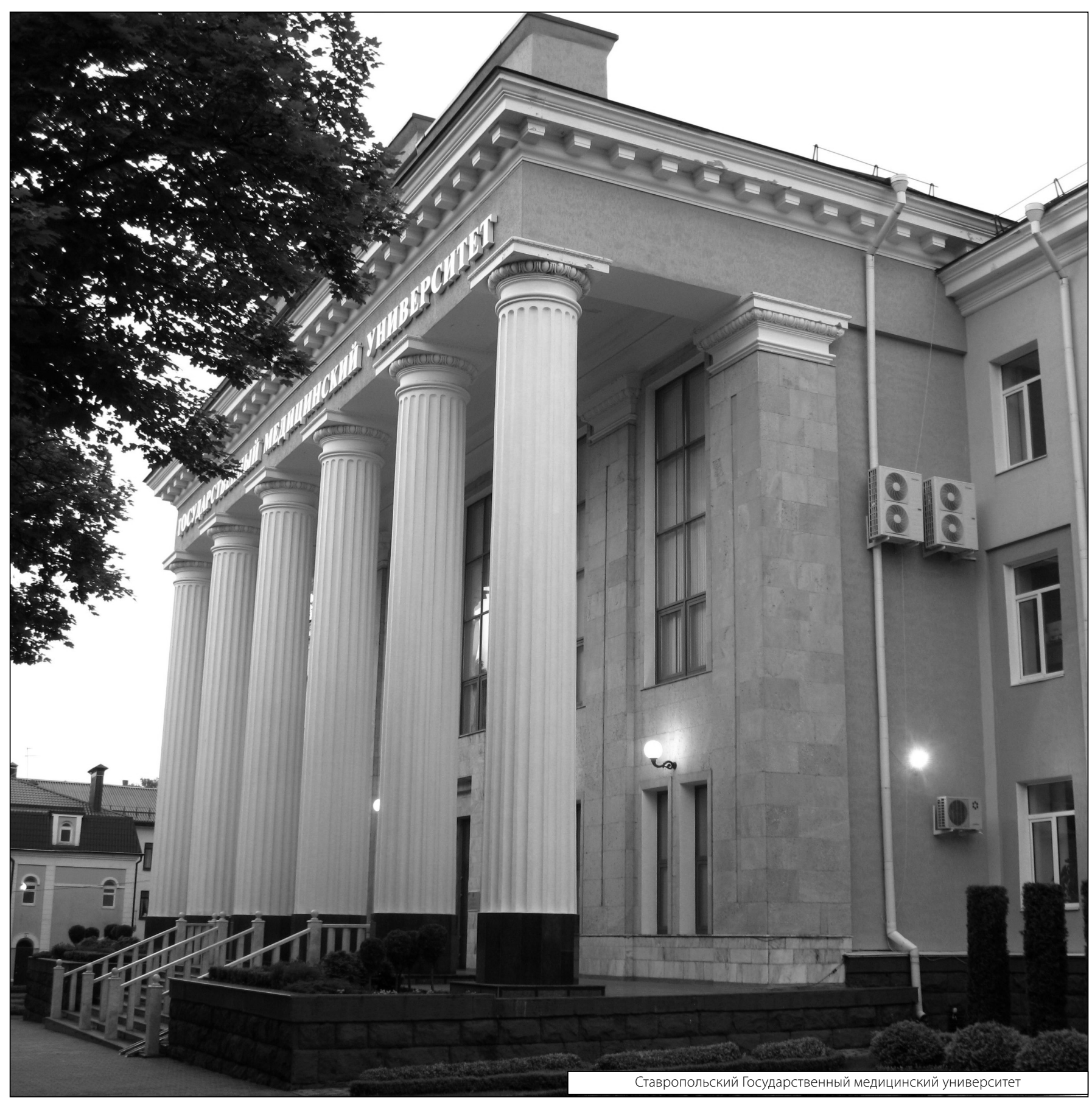

